\title{
Cyclic Adenosine Monophosphate Prevents the Glucocorticoid-mediated Inhibition of Insulin Gene Expression in Rodent Islet Cells
}

\author{
Jacques Philippe, * Emanuele Giordano, * Aslan Gjinovci, ${ }^{\star}$ and Paolo Meda* \\ Departments of ${ }^{*}$ Genetics, Microbiology and Medicine, and ${ }^{\ddagger}$ Morphology, and ${ }^{\S}$ Division of Clinical Biochemistry, \\ Department of Medicine, Centre Médical Universitaire, 1211 Geneva 4, Switzerland
}

\begin{abstract}
Dexamethasone negatively regulates insulin gene expression in HIT-15 cells. In vivo, however, an excess of glucocorticoids results in an increase in insulin biosynthesis and peripheral hyperinsulinemia. To resolve this contradiction, we have studied the effects of dexamethasone in primary rat islet cells. We show here that dexamethasone decreases insulin mRNA levels in single islet cells, as in HIT-15 cells, but does not affect these levels in reaggregated islet cells and increases them in intact islets of Langerhans. Because cAMP is an important regulator of insulin gene expression and intracellular cAMP content may be decreased in single $\beta$ cells, we investigated whether cAMP could prevent the inhibitory effect of dexamethasone on insulin mRNA levels. In the presence of cAMP analogues, the inhibitory action of dexamethasone was not only prevented, but insulin mRNA increased to levels comparable to those observed when $C A M P$ analogues were used alone. We conclude that the insulin gene is negatively regulated by dexamethasone in single islet cells, but that other factors such as cAMP prevent this effect when the native environment of islet cells is preserved. Our results indicate that insulin gene regulation is influenced by cell to cell contacts within the islet, and that intracellular cAMP levels might be influential in this regulation. ( $J$. Clin. Invest. 1992. 90:2228-2233.) Key words: cyclic adenosine monophosphate $\bullet$ glucocorticoids $\bullet$ insulin
\end{abstract}

\section{Introduction}

Glucocorticoids are antagonistic to insulin and have major effects on glucose homeostasis (1). Increased production and decreased utilization of glucose account for the impaired glucose tolerance during glucocorticoid treatment. The decrease in glucose utilization is acompanied by elevated fasting and glucose-stimulated insulin levels reflecting insulin resistance of target organs. Furthermore, peripheral hyperinsulinemia correlates with islet $\beta$ cell hyperplasia. Despite numerous in vitro studies, it is still unclear whether glucocorticoids directly affect insulin biosynthesis and secretion (for review, see reference 1).

The $\beta$ cells are the only islet cell type expressing the glucocorticoid receptor (2). Using HIT-15 cells, we and others have recently shown that insulin biosynthesis is inhibited by dexa-

Address reprint requests to Dr. Philippe, Department of Genetics and Microbiology, Centre Medical Universitaire, 9, avenue de Champel, 1211 Geneva 4, Switzerland.

Received for publication 3 January 1992 and in revised form 16 April 1992.

J. Clin. Invest.

(c) The American Society for Clinical Investigation, Inc.

$0021-9738 / 92 / 12 / 2228 / 06 \quad \$ 2.00$

Volume 90, December 1992, 2228-2233 methasone $(3,4)$. This effect is mediated by glucocorticoid receptors, occurs posttranscriptionally, and necessitates "de novo" protein synthesis. These in vitro observations are somewhat contradictory to those made in vivo, where both increased insulin production and islet hyperplasia are observed. This apparent discrepancy may be explained if hyperinsulinemia were an indirect consequence of the glucocorticoid-induced changes in glucose production which would then override the direct inhibitory effects on insulin biosynthesis, and/or if HIT-15 cells were not an adequate model to explore insulin production. To investigate these possibilities, we studied insulin gene regulation in single islet cells, reaggregated islet cells, intact islets, and HIT-15 cells. We show here that the negative regulation of the insulin gene by dexamethasone that is observed in HIT-15 cells is also seen in isolated islet cells but not in reaggregated islet cells or intact islets. This difference may be at least partly explained by a change in the intracellular cAMP concentration.

\section{Methods}

Cell culture. HIT-15 cells, a gift from Dr. A. E. Boyd III (Baylor College of Medicine, Houston, Tx ), were cultured in RPMI-1640 with $11 \mathrm{mM}$ glucose, supplemented with $10 \%$ fetal calf serum, $100 \mathrm{U} / \mathrm{ml}$ penicillin, and $100 \mu \mathrm{g} / \mathrm{ml}$ streptomycin, under an atmosphere of $5 \% \mathrm{CO}_{2} .1 \mathrm{~h}$ before the experiments, culture medium was switched to RPMI- 1640 supplemented with $0.5 \%$ BSA. Experimental plates were exposed to dexamethasone (Sigma Chemical Co., St. Louis, MO) at different concentrations, plus or minus $10^{-3} \mathrm{M}$ 8-bromoadenosine $3^{\prime}, 5^{\prime}$-cyclic monophosphate and $10^{-5} \mathrm{M}$ 3-isobutyl-1-methyl-xanthine (both from Sigma Chemical Co.), together referred to as 8-BMP. . Dexamethasone (Sigma Chemical Co.) was dissolved in ethanol at a stock concentration of $10^{-3} \mathrm{M}$.

Preparation of rat islets. Rat islets were isolated from the pancreas of male Sprague-Dawley rats weighing 250-350 $\mathrm{g}$ by ductal injection of collagenase and Histopaque purification (5). Islets from one rat were used for each experimental condition. After isolation, the islets were cultured in RPMI-1640 supplemented with $11 \mathrm{mM}$ glucose and serum (as for HIT-15 cells) for $3 \mathrm{~h}$ and switched to 0.5\% BSA-containing RPMI-1640 medium $1 \mathrm{~h}$ before the experiments.

Isolation of islet cells. Islets of Langerhans were isolated from Sprague-Dawley rats as outlined above. To prepare single cells (6), the islets were incubated $15 \mathrm{~min}$ at room temperature in a Krebs-Ringer bicarbonate medium prepared without $\mathrm{Ca}^{2+}$ and supplemented with $11.2 \mathrm{mM}$ glucose, $0.5 \% \mathrm{BSA}$, and $3 \mathrm{mM}$ EGTA. They were then disrupted by sequential aspirations through 18-, $21-$, and 25 -gauge needles (three aspirations per needle). The mixture of single cells and clumps obtained was incubated $3 \mathrm{~min}$ at room temperature within a slow rotating spinner flask containing a calcium-free medium and $0.1 \%$ trypsin (1:250; Difco Laboratories, Inc., Detroit, MI) (7). The resulting suspension was diluted with an excess of RPMI-1640 supplemented with penicillin and streptomycin and centrifuged for $5 \mathrm{~min}$ at $130 \mathrm{~g}$.

1. Abbreviation used in this paper: 8-BMP, 8-bromoadenosine 3',5'cyclic monophosphate. 
Cells were washed with the same medium three times and, for isolated cells, aliquots of 170,000-250,000 cells were seeded in $4 \mathrm{ml}$ of RPMI medium within $60-\mathrm{mm}$ dishes which prevented cell attachment (No. 1007, Falcon Plastics, Oxnard, CA). Eight such dishes were prepared for each experimental condition and the experiments were repeated three times. To prepare reaggregated islet cells, aliquots of $1,350,000$ cells were diluted in $3 \mathrm{ml}$ of RPMI medium. After $24 \mathrm{~h}$ of culture at $37^{\circ} \mathrm{C}$, dexamethasone and/or 8-BMP were added for a further $24-\mathrm{h}$ period. After $48 \mathrm{~h}$ of culture, more than $90 \%$ of the cells were aggregated and for single cell plates, $\sim 80 \%$ of the cells were still single.

Northern blot analysis. Cells (single islet cells, reaggregated islet cells, isolated islets, or HIT-15 cells) were collected, lysed in guanidine thyocyanate, and sonicated before centrifugation through a cesium chloride gradient. $5 \mu \mathrm{g}$ (single islet cells, reaggregated islet cells, and isolated islets) or $20 \mu \mathrm{g}$ (HIT-15 cells) of total RNA were electrophoresed, size-fractionated on a $1.4 \%$ agarose gel, and electroblotted onto a nylon membrane (Nytran, Schleicher \& Schuell, Inc., Keene, NH). RNA was fixed to the membrane by ultraviolet light. Prehybridization was carried out in $1 \mathrm{M} \mathrm{NaCl}, 1 \% \mathrm{SDS}, 10 \%$ dextran sulfate at $60^{\circ} \mathrm{C}$ for 2 $\mathrm{h}$ and hybridized with cDNA probes $\left(\sim 5 \times 10^{5} \mathrm{cpm} / \mathrm{ml}\right)$ in the same buffer and at the same temperature for $24 \mathrm{~h}$. Blots were washed at $60^{\circ} \mathrm{C}$ in $1 \times \mathrm{SSC}(0.15 \mathrm{M} \mathrm{NaCl}, 0.015 \mathrm{M}$ sodium citrate), $1 \% \operatorname{SDS}(4)$. cDNA probes (hamster insulin, rat glucagon, somatostatin, and $\beta$-actin) were labeled by random primer labeling according to the manufacturer's recommendations (Promega Corp., Madison, WI) (4).

\section{Results}

Dexamethasone has opposite effects on insulin gene expression in single islet cells compared to intact pancreatic islets. We first investigated dexamethasone effects on insulin gene expression in intact isolated rat islets. Total RNA was extracted from both control and dexamethasone $\left(10^{-6} \mathrm{M}\right)$-treated islets $(24 \mathrm{~h})$ and
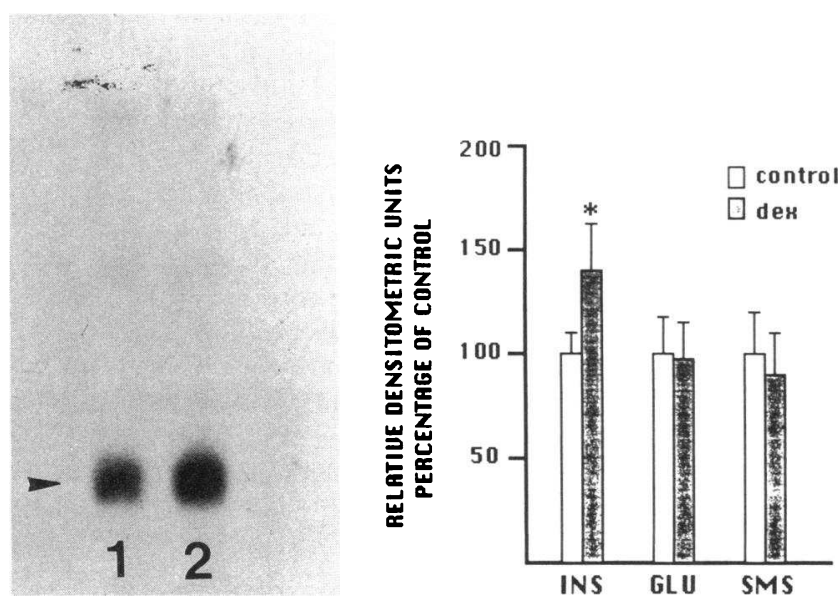

Figure 1. Dexamethasone increases insulin mRNA levels in isolated islets. Total RNA was extracted from isolated islets cultured for 24 $h$ in the absence (control) or presence of dexamethasone $\left(10^{-6} \mathrm{M}\right)$. (Left panel) Each lane contains $5 \mu \mathrm{g}$ of total RNA: lane 1 , control islets; lane 2 , islets treated with dexamethasone. Blots were hybridized with hamster ${ }^{32} \mathrm{P}$-labeled insulin CDNA probes. The arrowhead points to insulin mRNA. (Right panel) Quantification of mRNAs by densitometric scanning of the autoradiograms. Results are given as means \pm SEM of three experiments and expressed as percentage of controls. Open columns show the levels of insulin (INS)-, glucagon $(G L U)$-, and somatostatin (SMS)-specific mRNAs which were corrected by the relative amounts of $\beta$-actin mRNA in each respective lane. Solid columns show the corresponding values in the islets exposed to dexamethasone. ${ }^{*}$ Statistically significant differences $(P$ $<0.05)$. subjected to Northern analysis. Dexamethasone increased insulin mRNA levels by $42 \%$ in isolated islets without affecting glucagon and somatostatin mRNAs (Fig. 1). Because these results differed from those we reported in cultures of HIT-15 cells (4), we tested whether the insulin gene would be regulated in a similar fashion in primary rat islet cells dispersed from isolated islets. For each experimental condition single islet cells were isolated from six rats and dispersed in eight $60-\mathrm{mm}$ culture plates. Under these conditions, $<20 \%$ of the cells formed aggregates after $2 \mathrm{~d}$ of culture, the time at which total RNA was extracted. In the dexamethasone-treated cells, insulin mRNA levels were decreased to $46 \%$ of control value (Fig. 2), an effect qualitatively similar to that observed in cultures of HIT- 15 cells (see Fig. 4). This decrease was specific for insulin mRNA inasmuch as neither glucagon nor somatostatin mRNAs were con-
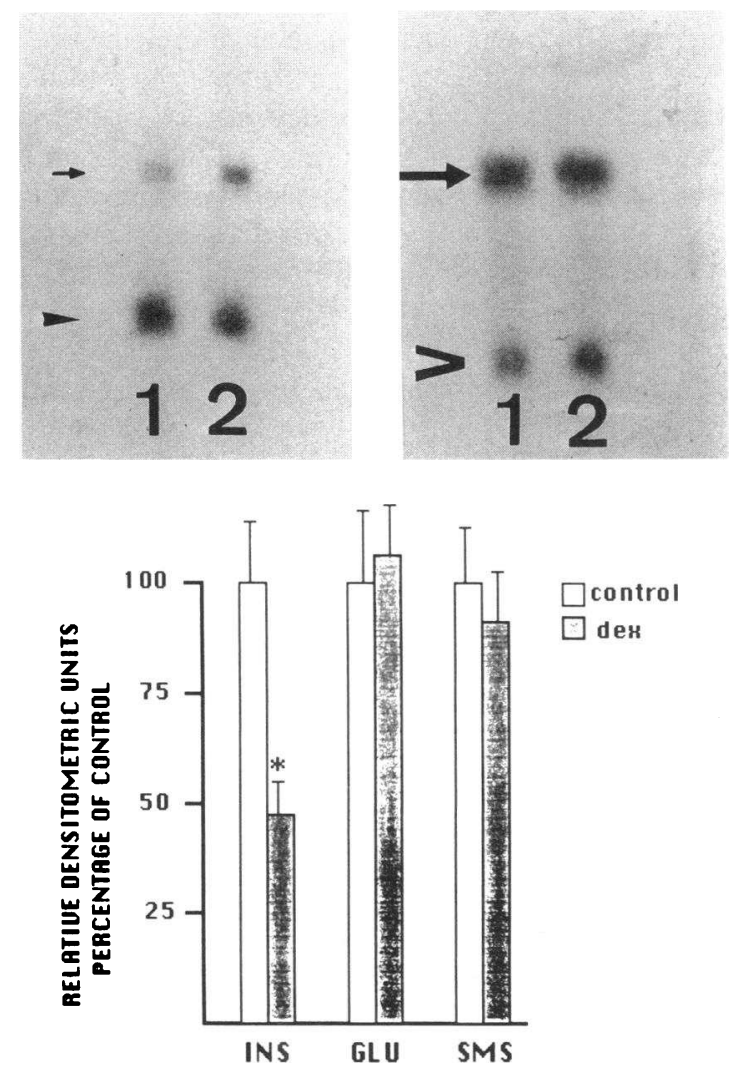

Figure 2. Dexamethasone effect on insulin gene expression in single rat islet cells. Total RNA was extracted from isolated islet cells cultured for $24 \mathrm{~h}$ in the absence (control) or presence of $10^{-6} \mathrm{M}$ dexamethasone and analyzed by Northern blot. (Top left panel) Each lane contains $5 \mu \mathrm{g}$ of total RNA: lane 1, control islet cells; lane 2, islet cells treated with dexamethasone. Blots were hybridized with hamster insulin and rat glucagon ${ }^{32} \mathrm{P}$-labeled cDNAs. The arrowhead indicates insulin mRNA and the arrow indicates glucagon mRNA. (Top right panel) After elimination of the insulin and glucagon-specific probes, blots were hybridized with rat somatostatin and rat ${ }^{32} \mathrm{P}$-labeled $\beta$-actin cDNAs. > indicates somatostatin mRNA and the arrow indicates $\beta$-actin mRNA. (Lower panel) Quantification of each mRNA by densitometric scanning of the autoradiograms. Values are means \pm SEM of three experiments and are expressed as percentage of controls. Open columns show the levels of insulin (INS)-, glucagon $(G L U)$-, and somatostatin ( $S M S)$-specific mRNAs which were corrected for the corresponding level of $\beta$-actin. Solid columns show the values observed in the presence of dexamethasone. *Statistically significant differences $(P<0.01)$ 
sistently modified by dexamethasone (Fig. 2). Similarly, the level of the $\beta$-actin signal, used as an internal control, did not change significantly in the presence of dexamethasone (Fig. 2). These data are compatible with the hypothesis that insulin gene expression can be differentially modulated depending on whether $\beta$ cells are single or aggregated within an islet.

cAMP analogues prevent the dexamethasone effect on insulin gene expression. A major difference between single $\beta$ cells and $\beta$ cells of intact islets is intracellular cAMP content. Dispersed $\beta$ cells indeed contain $40 \%$ less cAMP than reported in isolated islets ( 8 ). In addition, dispersed $\beta$ cells exhibit an insulin secretory response to glucose or amino acids that is two- to fivefold lower when compared with that of $\beta$ cells within intact islets $(8,9)$. This impaired response can be normalized by the addition of cAMP analogues to purified $\beta$ cells (8). Thus, we have investigated whether the inhibitory action of dexamethasone on insulin gene expression can also be modulated by cAMP. Single $\beta$ cells were incubated with dexamethasone alone $\left(10^{-6} \mathrm{M}\right), 8$-BMP alone, or dexamethasone and 8-BMP for $24 \mathrm{~h}$. Dexamethasone decreased insulin mRNA levels by $52 \%$ (Fig. 3). By contrast, 8-BMP induced a 3.7-fold increase. When cells were treated with both 8-BMP and dexamethasone $\left(10^{-6} \mathrm{M}\right)$, the negative effects of dexamethasone were no longer observed. Rather, the insulin mRNA changes were similar to those seen with 8-BMP alone (Fig. 3). Thus insulin mRNA was fourfold higher than in control cells. To investigate the effect of cell contacts on insulin gene expression, isolated islet cells were plated at high density to favor spontaneous reaggregation. Under conditions causing the clustering of $>90 \%$ of the islet cells, insulin mRNA levels were increased threefold compared to levels observed in isolated cells and dexamethasone had no effect. Interestingly, glucagon mRNA also increased by twofold in islet cells reaggregated compared to single islet cells and no change was caused by dexamethasone. In these experiments, isolated islet cells thus behaved similarly to HIT-15 cells.

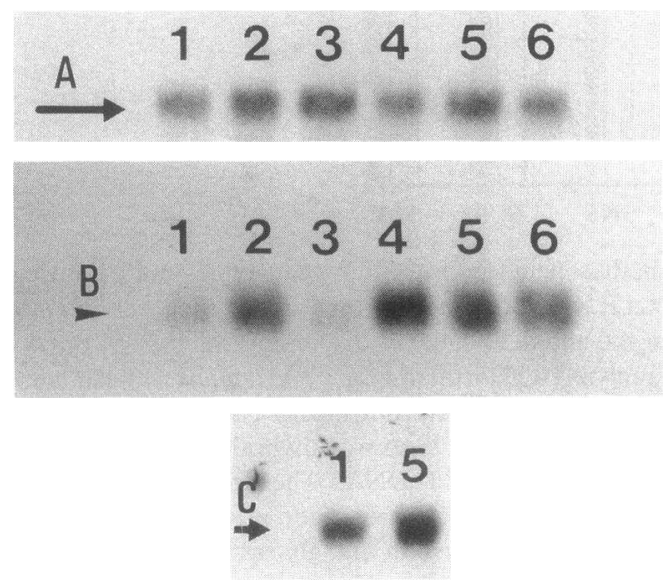

Figure 3. cAMP and cell reaggregation prevent the dexamethasoneinduced inhibition of insulin gene expression. Single (lanes 1-4) and reaggregated (lanes 5 and 6 ) primary islet cells were isolated and seeded as described in Methods. Total RNA was extracted after $24 \mathrm{~h}$ of cultures in the absence (lanes 1 and 5 ) or presence of dexamethasone at $10^{-6} \mathrm{M}$ (lanes 3 and 6), 8-BMP (lane 2), 8-BMP and dexamethasone at $10^{-6} \mathrm{M}$ (lane 4). Each lane contains $5 \mu \mathrm{g}$ of total RNA. Blots were hybridized with ${ }^{32} \mathrm{P}$-labeled rat $\beta$-actin $(A)$, hamster insulin $(B)$, and rat glucagon $(C)$ cDNAs.
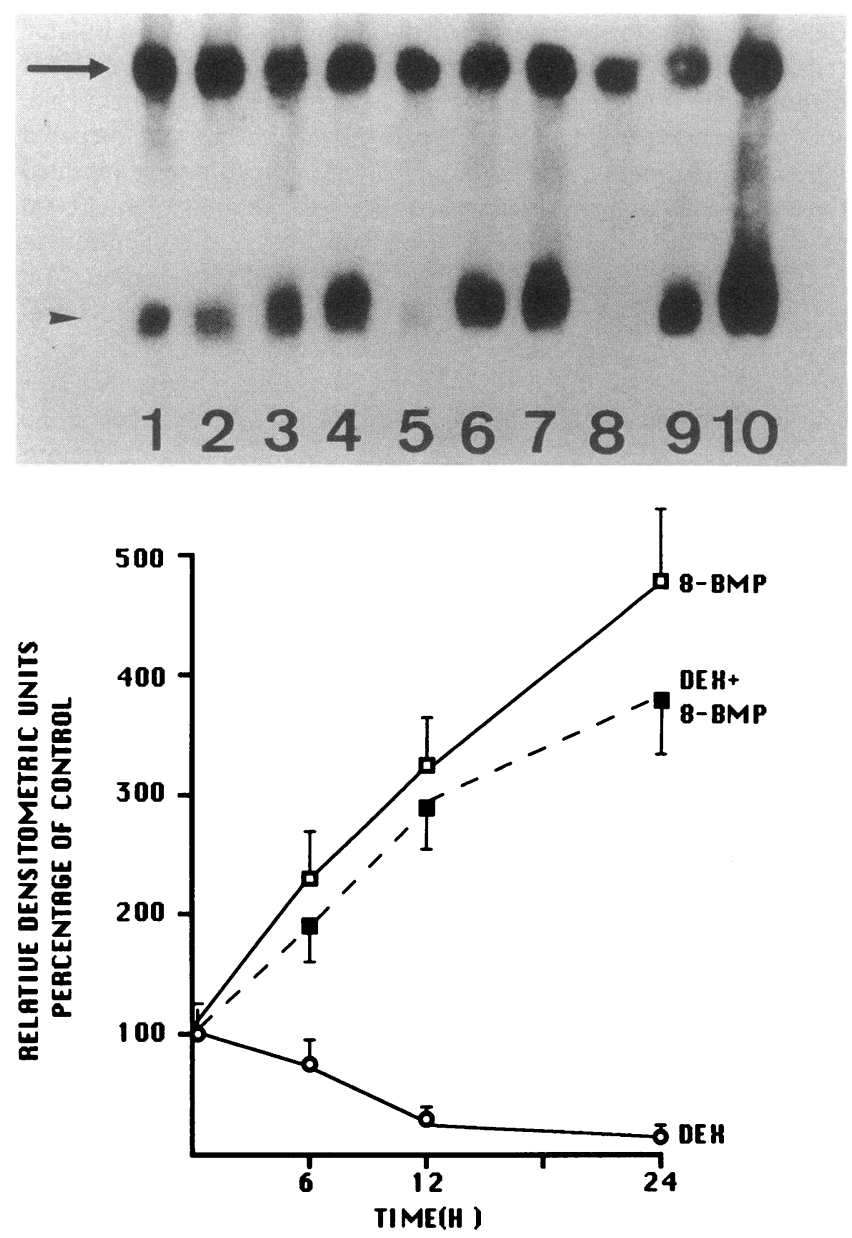

Figure 4. cAMP prevents the dexamethasone-mediated inhibition of insulin gene expression in HIT- 15 cells. HIT-15 cells were incubated for 6,12 , and $24 \mathrm{~h}$ with dexamethasone $\left(10^{-6} \mathrm{M}\right), 8$-BMP, or dexamethasone $\left(10^{-6} \mathrm{M}\right)+8$-BMP. Total RNA was extracted at the different time points and subjected to Northern analysis. (Top panel) Each lane contains $20 \mu \mathrm{g}$ of total RNA: control cells, lane 1; cells treated with dexamethasone, lane $2(6 \mathrm{~h})$, lane $5(12 \mathrm{~h})$, and lane 8 $(24 \mathrm{~h})$; cells treated with 8-BMP, lane $4(6 \mathrm{~h})$, lane $7(12 \mathrm{~h})$, and lane $10(24 \mathrm{~h})$; cells treated with dexamethasone and 8-BMP, lane 3 $(6 \mathrm{~h})$, lane $6(12 \mathrm{~h})$, and lane $9(24 \mathrm{~h})$. Blots were hybridized with ${ }^{32} \mathrm{P}$-labeled hamster insulin (arrowhead) and $\beta$-actin (arrow) cDNAs. (Bottom panel) Quantification of insulin mRNA levels by densitometric analyses of the autoradiograms. Results are means \pm SEM of three experiments and are expressed as in Figs. 1 and 2. Levels of insulin mRNAs were corrected for the relative $\beta$-actin mRNA signals.

The kinetics of the changes in insulin mRNA levels in response to dexamethasone and CAMP were studied in HIT-15 cells. As previously reported (4), dexamethasone markedly decreased insulin mRNA at 12 and $24 \mathrm{~h}$ as opposed to 8-BMP which resulted in a progressive rise which was significant after 6 $\mathrm{h}$ and maximal at $24 \mathrm{~h}$ (Fig. 4). The combination of 8-BMP and dexamethasone induced changes comparable to those seen with 8-BMP alone (Fig. 4).

We also examined how different concentrations of dexamethasone combined to cAMP analogues would affect the abundance of insulin mRNA in HIT-15 cells. $10^{-10} \mathrm{M}$ dexamethasone together with 8-BMP had the same effect as 8-BMP alone (Fig. 5). However, increasing concentrations of dexamethasone $\left(10^{-8}\right.$ and $\left.10^{-6} \mathrm{M}\right)$ resulted in an inhibition of insu- 

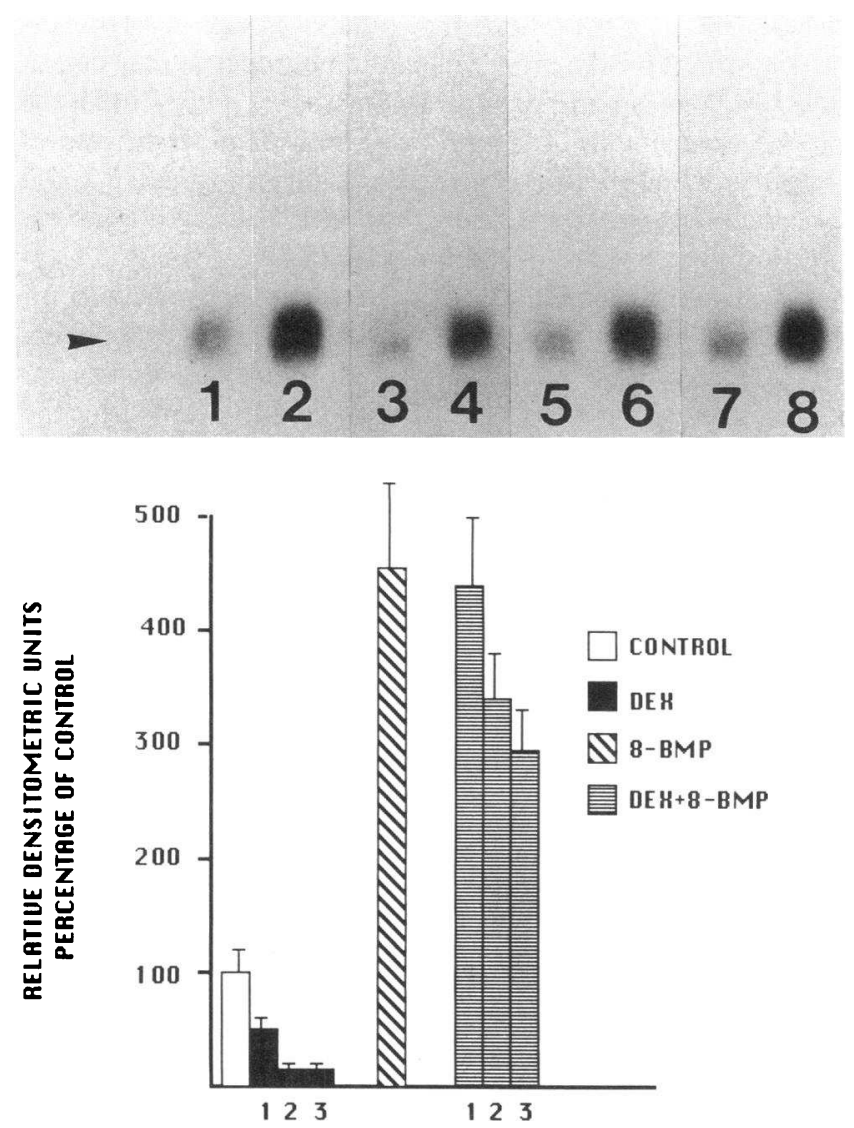

Figure 5. The effect of 8-BMP on insulin gene expression is modulated by dexamethasone concentration. HIT-15 cells were incubated with 8-BMP and different concentrations of dexamethasone $\left(10^{-6}\right.$, $10^{-8}$, and $10^{-10} \mathrm{M}$ ) for $24 \mathrm{~h}$. Total mRNA was then analyzed by Northern blot. ( Top panel) Each lane contains $20 \mu \mathrm{g}$ of total mRNA. Blots were hybridized with ${ }^{32} \mathrm{P}$-labeled insulin cDNA probe (arrowhead): control cells, lane 1 ; cells treated with 8-BMP, lane 2; cells treated with dexamethasone, lane $3\left(10^{-6} \mathrm{M}\right)$, lane $5\left(10^{-8} \mathrm{M}\right)$, and lane $7\left(10^{-10} \mathrm{M}\right)$; cells treated with 8-BMP and dexamethasone, lane $4\left(10^{-6} \mathrm{M}\right)$, lane $6\left(10^{-8} \mathrm{M}\right)$, and lane $8\left(10^{-10} \mathrm{M}\right)$. (Bottom panel) Quantification of insulin mRNA levels by densitometry. Values are means \pm SEM of three different experiments and are expressed as in Fig. 3. The open columns show the control levels equal to $100 \%$. The solid columns show the effects of dexamethasone alone. The crosshatched columns indicate the effects of 8-BMP alone and the horizontally-hatched columns those of the combination of dexametha-

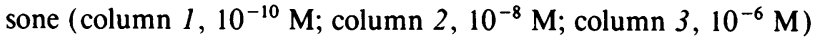
and 8-BMP. *Statistically significant differences $(P<0.002$ between control and 8-BMP; $P<0.05$ between 8-BMP and 8-BMP + dexamethasone $10^{-8} \mathrm{M} ; P<0.05$ between 8 -BMP and 8-BMP + dexamethasone $10^{-6} \mathrm{M}$ ). Levels of hormone-specific mRNAs were corrected for the $\beta$-actin mRNA signal.

lin gene expression (Fig. 5), although insulin mRNA levels remained at least threefold above controls. These results indicate that insulin gene expression is modulated in opposite ways by dexamethasone and cAMP analogues and that CAMP analogues have a dominant effect.

\section{Discussion}

We have found that dexamethasone inhibits insulin gene expression in single islet cells and HIT- 15 cells but increases it in intact pancreatic islets. We have also found that an analogue of cAMP not only prevents the inhibitory effects of dexamethasone on single islet cells and HIT-15 cells but actually results in a net increase in insulin mRNA levels, which are then comparable to those observed when the cAMP analogue is used alone. These findings suggest that the insulin gene is regulated differently depending on the environment of $\beta$ cells, and that cAMP plays a predominant role in this regulation. The importance of the environment for insulin gene expression is reinforced by the observation that the basal level of insulin mRNA is higher in reaggregated than in single islet cells. Cell environment may also be critical to maximize glucagon gene expression as the level of glucagon mRNA was also higher in reaggregated cells. In this context, it is of interest to note that the glucagon gene like the insulin gene, is regulated by a protein kinase A-activated pathway $(10,11)$.

Intracellular cAMP content is critical in the process of insulin secretion and also of insulin biosynthesis through direct effects on insulin gene expression. Analogues of cAMP stimulate insulin mRNA levels in normal rat and human islets as well as in HIT-15 and RIN 5-F insulinoma cells (12-15). We have recently characterized a cAMP-responsive DNA element within the 5'-flanking sequences of the rat insulin I gene which mediates the regulation of insulin gene transcription in response to changes in intracellular cAMP levels (15). Under both basal and stimulated conditions, cAMP levels appear important for maximal insulin gene expression, inasmuch as deletion of the cAMP-responsive DNA element results in decreased expression of the gene (15). The mechanisms by which cAMP analogues abolish the effects of dexamethasone on single islet cells or HIT-15 cells are not clear. The cAMP-induced increase in transcriptional rate of the insulin gene we previously reported in HIT-15 cells (fourfold over basal activity) (15) would be expected to compensate for the decreased stability of the insulin mRNA in the presence of dexamethasone (4). However, because the net effect of the dexamethasone-cAMP combination is at least a threefold increase in insulin mRNA, it is likely that additional mechanisms are involved. Phosphorylation and functional activation of steroid receptors by CAMP. dependent protein kinase A have been clearly documented (16, 17). Thus, direct interactions between the cAMP-dependent pathway and steroid receptor activation may be operative in modulating gene expression. In addition, the synthesis of the cAMP-responsive element binding protein that mediates the cAMP-induced changes in gene transcription is markedly increased by dexamethasone (18). Our data, however, do not distinguish between these possibilities leaving presently unanswered the question of whether the dexamethasone-cAMP combination affects insulin gene transcription through a transcriptional, a posttranscriptional, or both mechanisms.

The observation that dexamethasone caused a decrease in the expression of the insulin gene in both HIT-15 cell cultures and dispersed islet cells is in apparent contradiction with the in vivo observation that glucocorticoids increase insulin biosynthesis ( 1). Our data indicate that this discrepancy is mostly due to the in vitro conditions under which islet cells were tested. Indeed, using intact pancreatic islets, a preparation in which $\beta$-cells retain at least in part their native in situ environment, we have found that dexamethasone increases insulin mRNA levels. This change may result in part from the lack of the glucocorticoid-induced inhibition, presumably due to the promoting effect of coexisting cAMP. However, it is unlikely that 
such a lack of inhibitory effect alone could account for the $40 \%$ increase in the steady state levels of insulin mRNA we observed. Rather, it is most likely that this net increase reflects also the involvement of other positive factors, such as the increased synthesis of the cAMP-responsive element binding protein (18). Because the regulation of the insulin gene is defective in dispersed islet cells, these factors should be somehow dependent on the maintenance of the contacts $\beta$ cells normally establish within the islets of Langerhans. The absence of inhibitory effects of dexamethasone on reaggregated islet cells strengthen this hypothesis.

In view of the stimulatory effects of glucose on insulin biosynthesis, which may be partly mediated by an increase in gene transcription, it is of importance to note that our data on primary islet cells were obtained in the presence of $11 \mathrm{mM}$ glucose. We previously postulated that increased transcription in response to glucose could occur through the cAMP-responsive DNA element of the insulin gene, thus implicating cAMP as the second messenger. This view has, however, been recently challenged by the characterization of a more distal DNA control element responsible for the glucose-induced effects on gene transcription (19). Furthermore, in this study, but not in another (20), calcium was proposed as a possible mediator. Our present data indicate that in single islet cells $11 \mathrm{mM}$ glucose was not sufficient to upregulate the insulin gene and that cell to cell contacts were critical. It is thus possible that glucose involves both a $\mathrm{Ca}^{2+}$ - and cAMP-dependent mechanism which may be linked inasmuch as increases in cAMP levels allow more calcium to enter the $\beta$ cell through the voltage-dependent calcium channel (19).

Whatever the additional mechanisms by which glucose exerts its effects, it is likely that they participate in the response of the insulin gene to dexamethasone. Single $\beta$ cells are known to release less insulin compared to aggregated $\beta$ cells and intact islets $(8,9)$. Homologous contacts have been shown to promote the recruitment of secreting $\beta$ cells and to increase two- to fivefold their individual release of insulin in the presence of glucose (9). The reasons for these changes remain to be fully elucidated. Intracellular levels of cAMP have been shown to be decreased in dispersed islet cell preparations (8), and this decrease may contribute to the poor glucose-stimulated insulin release of isolated $\beta$ cells. Indeed, insulin secretion is at least partially corrected by cAMP analogues ( 8 ). In view of the promoting effect of cAMP on the expression of the insulin gene, it is therefore possible that a low intracellular level of cAMP also contributes to decreased levels of insulin mRNA. No data comparing intracellular cAMP in HIT-15 cells and intact islets are available. However, previous studies suggest that HIT-15 cells have a cAMP metabolism which is different from that of intact islets, particularly in response to glucose (21-23). Furthermore, HIT-15 cells show a low basal level of insulin gene transcription and no transcriptional response to glucose (19).

Recent evidence suggests that junctional communications rapidly improve the insulin release of individual $\beta$ cells (24). Because these communications have the potential of ensuring that $\beta$ cells share diffusible mediators and second messengers of the cAMP size at specialized cell-cell contacts $(25)$, they could be influential in regulating the expression of the insulin and glucagon genes. One would then expect that this regulation is pertubed when gap junction contacts are disrupted or not established. This is precisely the case in preparations of dispersed islet cells and in monolayer cultures of HIT-15 cells, respec- tively (26). The hypothesis that junctional cell-cell contacts are important for the proper regulation of the insulin gene can now be tested experimentally. We must stress however that the present experiments do not allow us to distinguish the respective roles of homologous $(\beta-\beta, \alpha-\alpha)$ and heterologous $(\alpha-\beta)$ cell to cell contacts in upregulating insulin and glucagon gene expression.

In any case, regulation of the insulin gene appears to involve both dexamethasone and cAMP. The glucocorticoid exerts a direct inhibitory effect on insulin gene expression as observed in single islet cells but this effect is prevented by the dominant positive action of cAMP. Furthermore, our data indicate that the net effect on insulin biosynthesis will be modulated both by the glucocorticoid concentration and the intracellular level of cAMP. The relevance of these in vitro findings to the situation prevailing in vivo remains to be assessed. In the presence of excess glucocorticoids, increased glucose production might upregulate insulin biosynthesis by further increasing intracellular cAMP levels $(27,28)$. This upregulation could contribute to the marked hyperinsulinemia observed during glucocorticoid treatment.

In conclusion, our studies indicate that the regulation of the insulin gene is modulated by the environment of $\beta$ cells, suggesting that cell to cell interactions are critical to maximize gene expression.

\section{Acknowledgments}

We thank Rachel Zanone, Anne Charollais, Luisa Iuliano, and Pilar Ruga for excellent technical help, and Marie de Peyer for typing the manuscript.

This work was supported by grants from the Swiss National Science Foundation (3.851-0.88 to Dr. Philippe and 32-34090.92 to Prof. Meda) and the Sir Jules Thorn Foundation (to both Philippe and Meda) and the Juvenile Diabetes Foundation International (192467 to Prof. Meda).

\section{References}

1. Lenzen, S., and J. Bailey. 1984. Thyroid hormones, gonadal and adrenocortical steroids and the function of the islets of Langerhans. Endocr. Rev. 5:411434.

2. Fisher, B., U. Rausch, P. Wollny, H. Westphal, J. Seitz, and G. Aumüller. 1990. Immunohistochemical localization of the glucocorticoid receptor in pancreatic $\beta$-cells of the rat. Endocrinology. 126:2635-2641.

3. Gold, G., R. L. Qian, and G. M. Grodsky. 1988. Biosynthetic regulation of endogenous hamster insulin and exogenous rat insulin II in transfected HIT-15 cells. Diabetes. 37:160-164.

4. Philippe, J., and M. Missotten. 1990. Dexamethasone inhibits insulin biosynthesis by destabilizing insulin mRNA in hamster insulinoma cells. Endocrinology. 127:1640-1645.

5. Sutton, R., M. Peters, P. McSchane, D. W. R. Gray, and P. J. Morris. 1986. Isolation of rat pancreatic islets by ductal injection of collagenase. Transplantation. 42:689-691.

6. Wollheim, C. B., P. Meda, and P. A. Halban. 1990. Isolation of pancreatic islets and primary culture of the intact microorgans and dispersed islet cells. Methods Enzymol. 192:188-223.

7. Meda, P., E. L. Hooghe-Peters, and L. Orci. 1980. Monolayer cultures of adult pancreatic islet cells on osmotically disrupted fibroblasts. Diabetes. 29:497500.

8. Pipeleers, D. G., F. C. Schuit, P. A. In't Veld, E. Maes, E. L. Hooghe-Peters, M. Van de Winkel, and W. Gepts. 1985. Interplay of nutrients and hormones in the regulation of insulin release. Endocrinology. 117:824-833.

9. Bosco, D., L. Orci, and P. Meda. 1989. Homologous but not heterologous contact increases the functioning of individual secretory cells. Exp. Cell Res. 184:72-80.

10. Drucker, D. J., R. Campos, R. Reynolds, K. Stobie, and P. L. Brubaker. 1991. The rat glucagon gene is regulated by a protein kinase A-dependent pathway in pancreatic islet cells. Endocrinology. 128:394-400. 
11. Knepel, W., J. Chafitz, and J. F. Habener. 1990. Transcriptional activation of the rat glucagon gene by the cyclic AMP-responsive element in pancreatic islet cells. Mol. Cell. Biol. 10:6799-6804.

12. Nielsen, D. A., M. Welsch, M. Casadaban, and D. F. Steiner. 1985. Control of insulin gene expression in pancreatic $\beta$ cells and in an insulin-producing cell line, RIN 5F cells. I. Effects of glucose and cAMP on the transcription of insulin mRNA. J. Biol. Chem. 260:13585-13589.

13. Welsch, M., D. A. Nielsen, A. J. McKrell, and D. F. Steiner. 1985. Control of insulin gene expression in pancreatic $\beta$ cells and in an insulin-producing cell line, RIN 5F cells. II. Regulation of insulin mRNA stability. J. Biol. Chem. 260:13590-13594.

14. Hammonds, P., P. N. Schofield, S. J. H. Ashcroft, R. Sutton, and D. W. R. Gray. 1987. Regulation and specificity of glucose-stimulated insulin gene expression in human islets of Langerhans. FEBS (Fed. Eur. Biochem. Soc.) Lett. 223:131-137.

15. Philippe, J., and M. Missotten. 1990. Functional characterization of a cAMP responsive element of the rat insulin I gene. J. Biol. Chem. 265:14651469.

16. Power, R. F., J. P. Lydon, O. M. Conneely, and B. M. O’Malley. 1991 Dopamine activation of an orphan of the steroid receptor superfamily. Science (Wash. DC). 252:1546-1548.

17. Denner, L. A., N. L. Weigel, B. L. Maxwell, W. T. Schrader, and B. W. O'Malley. 1990. Regulation of progesterone-mediated transcription by phosphorylation. Science (Wash. DC). 250:1740-1743.

18. Jungmann, R. A., X. Wang, D. M. Milkowski, and M. L. Short. 1992. Glucocorticoid induction of CRE-binding protein isoform mRNAs in rat C6 glioma cell. Nucleic Acids Res. 20:825-829.

19. German, M. S., L. G. Mass, and W. J. Rutter. 1990. Regulation of insulin gene expression by glucose and calcium in transfected primary islet cultures. $J$. Biol. Chem. 265:22063-22066.

20. Welsh, M., T. Weber, O. Wrange, D. A. Nielsen, M. Matthieu, and D. F. Steiner. 1988. Regulation of insulin gene expression by dexamethasone, $\mathrm{Ca}^{++}$ and a phorbol ester. Biomed. Biochim. Acta. 47:299-303.

21. Ascroft, S. J. H., P. Hammonds, and D. E. Harrison. 1986. Insulin secretory responses of a clonal cell line of simian virus 40 -transformed B cells. Diabetologia. 29:727-733.

22. Hill, R. S., J. M. Oberwetter, and A. E. Boyd III. 1987. Increase in cAMP levels in $\beta$-cell line potentiates insulin secretion without altering cytosolic freecalcium concentration. Diabetes. 36:440-446.

23. Ullrich, S., and C. B. Wollheim. 1984. Islet cyclic AMP levels are not lowered during $\alpha_{2}$-adrenergic inhibition of insulin release. J. Biol. Chem. 259:4111-4115.

24. Meda, P., D. Bosco, M. Chanson, E. Giordano, L. Vallar, C. Wollheim and L. Orci. 1990. Rapid and reversible secretion changes during uncoupling of rat insulin-producing cells. J. Clin. Invest. 86:759-768.

25. Meda, P., M. Amherdt, A. Perrelet, and L. Orci. 1981. Metabolic coupling between cultured pancreatic $\beta$-cells. Exp. Cell. Res. 133:421-430.

26. Ullrich, S., V. Cirulli, and P. Meda. 1992. Expression of the gap junction protein connexin 43 in insulin-secreting cells. Eur. J. Cell. Biol. 57 (Suppl. 36):82.

27. Charles, M. A., J. Lawecki, R. Pictet, G. M. Grodsky. 1975. Insulin secretion. Interrelationships of glucose, cAMP and calcium. J. Biol. Chem. 250:61346140 .

28. Fiedorek, F. T., and M. A. Permutt. Proinsulin mRNA levels in fasting and fed ADX rats: evidence for an indirect effect of glucocorticoids. Am. J. Physiol. 256:E303-E308. 